\title{
Highlights of Marketing Research in Romania
}

\author{
Laura Catalina Țimiraş, „Vasile Alecsandri” University of Bacau, Romania \\ Bogdan Nichifor, ,,Vasile Alecsandri” University of Bacau, Romania \\ Luminița Zaiț, „,Vasile Alecsandri” University of Bacau, Romania
}

\begin{abstract}
Being in direct dependence with markets development - namely, with economic development level, intensity of competition and consumers demands - domestic marketing research market registered up to the year 2008 a sustained increased. More and more players have come at this market, as represented of both world famous organizations, and locally operating companies. Revenues from marketing research services showed significant annual increases for most market operators. So as expected, the economic crisis spread at this level too, the year 2009 marking the beginning of earnings decline in marketing research services. On the activity distribution point of view the research marketing market in Romania is a concentrated one, mainly dominated by a relatively small number of multinational companies.
\end{abstract}

\section{Keywords}

marketing, marketing research, turnover, market operators

\section{JEL Codes: M 31, D 83}

\section{Introductory Elements}

Marketing research has the purpose of providing information necessary for decision making. Virtually, at any time of its existence the organization needs information - information about the evolution and impact of macro-environment factors, as well as about the needs, demands, preferences, target consumer expectations, about the evaluation criteria considered by consumers in purchase decision and about what constitutes "value" for them, about the actions of competitors and their offerings, but also those of their suppliers or service providers about brand image and attitude toward their own products etc. Whatever marketing activity undertaken - a new product launching, or relocation of another, planning and operational program communication, selection of the used marketing channels and of suppliers, or establishing prices for certain products etc. - choosing from several action alternatives the one which ensures the best ratio between internal and external organization environmental conditions requires information. Not least, marketing research conducted in a continuous manner, that constitutes a feature of market-oriented organizations, allows the identification of various opportunities and avoidance of future hazards.

In fact, marketing research provides a whole arsenal of methods and techniques adapted to various situations faced by the organization: from qualitative research, where the obtained data is not a subject to quantification, some aimed at understanding the irrational and / or unconscious aspects of certain behaviours / events / processes, which require deeper investigation on the human psyche - to quantitative research that may require use of advanced methods for determining the causality of phenomena and to study the statistical significance of the obtained results. 


\section{Marketing research in Romania during 2005 - 2008}

Marketing research market in Romania was formed and developed especially on the account of the request of information shown by multinational companies which take action nationwide. ${ }^{1}$

Increased competition among different national markets and thus the need to provide to customers real competitive advantages, increasing demands and fast rhythm of change in requirements / consumer preferences have led to awareness in a large extent at the level of all organizations (those native inclusively) of the role and "value" of accurate, current, relevant and sufficient information ${ }^{2}$ for decision making. This, coupled with the growing number of foreign companies that entered the Romanian market, has generated an increasing demand for marketing information and implicitly printing of an uptrend on the reference market (at least up to 2008).

Table no. 1. Turnover (lei)* recorded by some of the most important market operators in marketing research in Romania, in 2005 -2008 period

\begin{tabular}{|c|c|c|c|c|c|c|}
\hline \begin{tabular}{l|} 
Nr. \\
Crt.
\end{tabular} & Organization name ** & web page & 2005 & 2006 & 2007 & 2008 \\
\hline 1 & ACNIELSEN ROMANIA, Bucharest & www.acnielsen.com & 6991795 & m.d. & 9087608 & 11314321 \\
\hline 2 & AD CONSULTING, Bucharest & www.adconsulting.ro & 2054447 & 1654875 & 2202840 & 2660522 \\
\hline 3 & ALFA CONT, Bucharest & www.alfacont.ro & 1282153 & 1708797 & 1864602 & 2899284 \\
\hline 4 & CEGEDIM ROMÂNIA, Bucharest & www.cegedim.ro & 9600454 & 11976499 & 15519410 & 18121221 \\
\hline 5 & $\begin{array}{l}\text { URBAN AND REGIONAL SOCIOLOGY CENTER - (URSC), } \\
\text { Bucharest }\end{array}$ & www.curs.ro & 1626688 & 2119020 & 2626727 & m.d. \\
\hline 6 & $\begin{array}{l}\text { CENTER FOR OPINION AND MARKET RESEARCH (COMR), } \\
\text { Bucharest }\end{array}$ & www.csop.ro & 2577425 & m.d. & 4062418 & 6296216 \\
\hline 7 & D\&D RESEARCH, Bucharest & www.ddresearch.ro & 574489 & 631436 & 1162246 & 849731 \\
\hline 8 & DAEDALUS CONSULTING, Bucharest & www.daedalusmb.ro & 5606736 & 7278257 & 8203971 & 12396446 \\
\hline 9 & EURODATA MANAGEMENT, Bucharest & www.eurodatamanagement.ro & 1665626 & 3448706 & 4753141 & 6972485 \\
\hline 10 & GFK ROMÂNIA, Bucharest & www.gfk-ro.com & 8638613 & 12367895 & 16625213 & 33127629 \\
\hline 11 & IMAS MARKETING \& BORING, Bucharest & www.imas-inc.com & 2961118 & 3848523 & 5055125 & 4389588 \\
\hline 12 & $\begin{array}{l}\text { INSOMAR -POLITIC RESEARCH AND MARKETING, } \\
\text { Bucharest }\end{array}$ & www.insomar.ro & - & - & 54476 & 4000684 \\
\hline 13 & INSOMAR, Bucharest & www.insomar.ro & 968993 & 3660751 & 1453619 & 1976012 \\
\hline 14 & $\begin{array}{l}\text { ROMANIAN INSTITUTE FOR SOCIO- ECONOMIC } \\
\text { RESEARCH AND BORING - IRECSON,Bucharest }\end{array}$ & www.irecson.ro & 4562048 & 4525715 & 4983299 & 5880215 \\
\hline 15 & IRSOP MARKET RESEARCH\& CONSULTING, București & www.irsop.ro & 3144936 & 2563070 & 2780223 & 3795518 \\
\hline 16 & ISRA CENTER MARKETING RESEARCH, Bucharest & www.isracenter.com & 1640375 & 3989389 & 4327912 & 5809704 \\
\hline 17 & MARKETSCOPE, Bucharest & www.marketscope.ro & 673803 & 443986 & 726221 & 1127876 \\
\hline 18 & MEDNET, Bucharest & www.romednet.com & 1117922 & m.d. & 1412417 & 2543489 \\
\hline 19 & $\begin{array}{l}\text { MEMRB ROMANIA RETAIL TRACKING SERVICES, } \\
\text { Bucharest }\end{array}$ & www.memrb.com & 7068846 & 7762983 & 11478214 & 11930440 \\
\hline 20 & MERCURY RESEARCH, Bucharest & www.mercury.ro & 5615451 & 6406870 & 5296788 & 7322684 \\
\hline 21 & METRO MEDIA TRANSILVANIA, Cluj & www.mmt.ro & 594188 & 1458086 & 2263526 & 2774395 \\
\hline 22 & $\begin{array}{l}\text { RESEARCH INTERNATIONAL - MARKET RESEARCH, } \\
\text { Bucharest }\end{array}$ & www.research-int.com & - & - & 887893 & 2542734 \\
\hline 23 & SYNOVATE, Bucharest & www.synovate.com & 7387393 & 10727464 & 17056710 & 14631127 \\
\hline 24 & THE GALLUP ORGANIZATION, ROMÂNIA, Bucharest & www.gallup.ro & 2197615 & 3543344 & 4290321 & 6413959 \\
\hline 25 & TNS AGB INTERNATIONAL, Bucharest & www.agbnielsen.net & 4534589 & 4933077 & 4977844 & 60292 \\
\hline & VISIONWISE CONSULTING, Bucharest & www.visionwise.ro & - & 421565 & 1089042 & 1340305 \\
\hline & $\begin{array}{l}\text { m.d. - missing data } \\
\text { ource: *http://www.mfinante.ro; } \\
\text { **Yearbook Media \& Advertising, Mediafa } \\
\text { **http://sociologie.dreamstyler.ro/marketing } \\
\text { **http://mcir.doingbusiness.ro/ro/servicii-pr }\end{array}$ & $\begin{array}{l}\text { ditions: } 2009 \text { and } 20 \\
\text {; }\end{array}$ & & & & \\
\hline
\end{tabular}

Romania being actually the country with the highest growth rate in 2008 as against 2007

\footnotetext{
${ }^{1}$ http://www.wall-street.ro/articol/Marketing-PR/12503/Cercetarea-de-marketing-o-piata-de-12milioane-euro.html.

${ }^{2}$ These are the 4 criteria for assessing marketing information.

${ }^{3}$ Source: ESOMAR (European Society for Opinion and Marketing Research).
} 
worldwide $-22.8 \%$. In the same year global market research marketing totalled around 21 billion Euros ${ }^{4}$.

Table no. 1 presents the turnovers of some of the well known marketing research organizations in Romania. Among these, the German company GfK, which works in over 90 countries worldwide, is a national market leader in the field, reaching in 2008 a turnover of over 33 million lei and a market share of $19,3 \%{ }^{5}$

Alongside GfK Romania, the most powerful marketing research market competitors in Romania are: Cegedim, Synovate, ACNielsen, MEMRB, Daedalus, Gallup and Mercury Research $^{6}$, the only domestic company among those listed being Daedalus. Figure no. 1 reflects the turnovers realized in 2008 by the main six companies that operate nationally and have exceeded the threshold of 10 million lei. In fact, the six companies, holding the first places in the hierarchy of marketing research organizations in Romania have achieved altogether revenues of 101.4 million lei, which represents over $55 \%$ of the total market. Therefore, we may state that marketing research market in Romania is a concentrated one, mainly dominated by multinational companies.

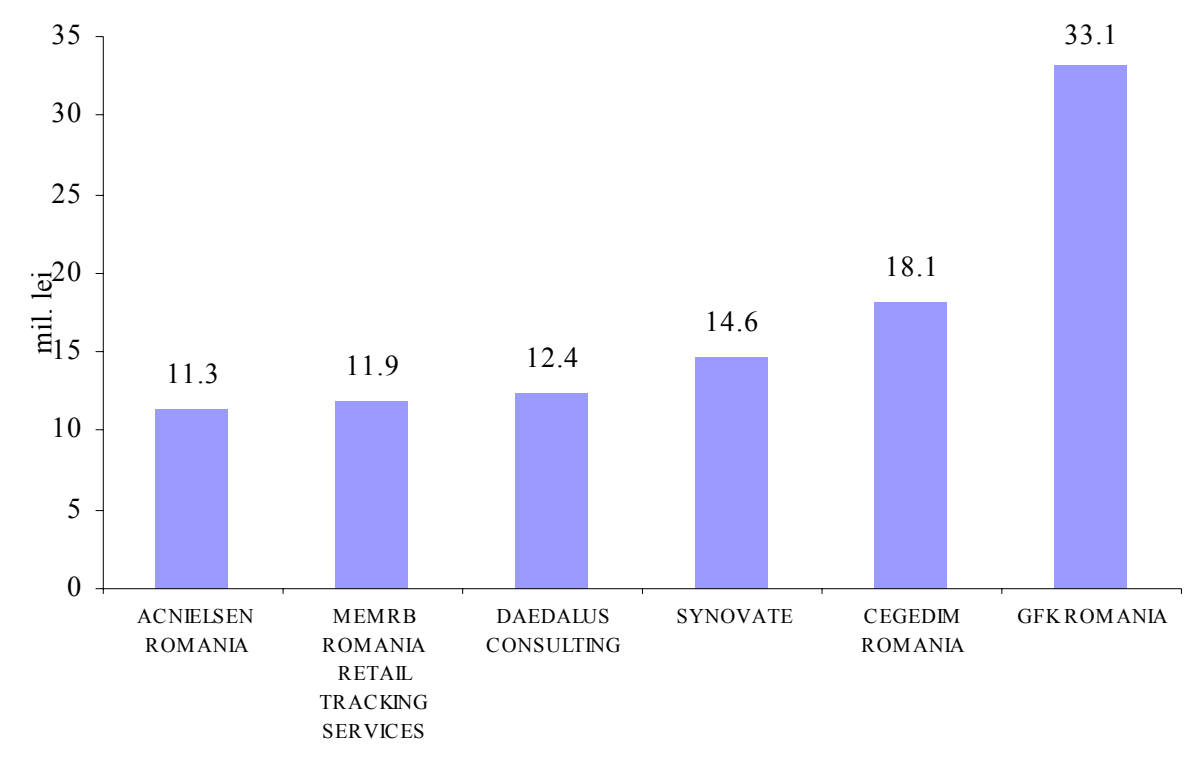

Figure no. 1. Turnover of the first 6 competitors in the market for marketing research in Romania, with values exceeding 10 million revenue in 2008 (million lei)

Source: processing by http://www.mfinante.ro/

Real turnover growth is observed for almost all studied organizations during 2005 - 2008, reaching in some cases over 200\% in 2008 compared with 2005 (Metro Media Transilvania, Eurodata Management, GfK Romania). In fact, 2008 represented in Romania's marketing

\footnotetext{
${ }^{4} \mathrm{http}: / /$ www.revista-piata.ro/articole/research/criza-ne-a-invatat-sa-fim-mai-ieftini-oferind-aceeasicalitate.html.

${ }^{5} \mathrm{http}$ //www.money.ro/cercetare-de-piata/gfk-romania-a-obtinut-in-primele-sase-luni-ale-anuluiafaceri-de-peste-16-5-milioane-lei.html.

${ }^{6}$ Main players on the national marketing research market were listed by the Wall Street journal, based on the turnover recorded in 2006. (Http://www.wall-street.ro/articol/Start-Up/40250/A-renuntat-la-unpost-de-manager-de-multinationala-pentru-a-si-infiinta-propria-afacere. html).
} 
research a reference year, with the largest revenue made by specialized companies. (Table no. 2).

Table no. 2. Change of the turnover recorded by some of the most important market operators in marketing research in Romania, during $2005-2008$ period $^{7}$

\begin{tabular}{|c|c|c|c|c|c|}
\hline \multirow{2}{*}{$\begin{array}{l}\text { Nr. } \\
\text { Crt. }\end{array}$} & \multirow{2}{*}{ Organization name } & \multicolumn{3}{|c|}{$\begin{array}{l}+/ \text { - in percents as against the } \\
\text { previous year }\end{array}$} & \multirow{2}{*}{$\begin{array}{l}+/ \text { - in } \\
\text { percents in year } \\
2008 \text { as against } \\
\text { the year } 2005\end{array}$} \\
\hline & & 2006 & 2007 & 2008 & \\
\hline 1 & AD CONSULTING, Bucharest & m.d. & m.d. & 15.4 & 34.3 \\
\hline 2 & ALFA CONT, Bucharest & -24.4 & 27.0 & 12.0 & 7.5 \\
\hline 3 & CEGEDIM ROMÂNIA, Bucharest & 25.1 & 4.1 & 44.2 & 87.7 \\
\hline 4 & $\begin{array}{l}\text { URBAN AND REGIONAL SOCIOLOGY } \\
\text { CENTER - (URSC), Bucharest }\end{array}$ & 17.1 & 23.6 & 8.3 & 56.7 \\
\hline 5 & $\begin{array}{l}\text { CENTER FOR OPINION AND MARKET } \\
\text { RESEARCH (COMR), Bucharest }\end{array}$ & 22.3 & 18.2 & m.d. & m.d. \\
\hline 6 & D\&D RESEARCH, Bucharest & m.d. & m.d. & 43.7 & 102.8 \\
\hline 7 & DAEDALUS CONSULTING, Bucharest & 3.2 & 75.6 & -32.2 & 22.8 \\
\hline 8 & EURODATA MANAGEMENT, Bucharest & 21.8 & 7.5 & 40.1 & 83.5 \\
\hline 9 & GFK ROMÂNIA, Bucharest & 94.3 & 31.5 & 36.0 & 247.5 \\
\hline 10 & IMAS MARKETING \& BORING, Bucharest & 34.4 & 28.2 & 84.8 & 218.3 \\
\hline 11 & $\begin{array}{l}\text { INSOMAR -POLITIC RESEARCH AND } \\
\text { MARKETING, Bucharest }\end{array}$ & 22.0 & 25.3 & -19.5 & 23.0 \\
\hline 12 & INSOMAR, Bucharest & m.d. & m.d. & 6709.4 & m.d. \\
\hline 13 & $\begin{array}{l}\text { ROMANIAN INSTITUTE FOR SOCIO- } \\
\text { ECONOMIC RESEARCH AND BORING - } \\
\text { IRECSON,Bucharest }\end{array}$ & 254.6 & -62.1 & 26.0 & 69.3 \\
\hline 14 & $\begin{array}{l}\text { IRSOP MARKET RESEARCH\& CONSULTING, } \\
\text { București }\end{array}$ & -6.9 & 5.0 & 9.4 & 7.0 \\
\hline 15 & $\begin{array}{l}\text { ISRA CENTER MARKETING RESEARCH, } \\
\text { Bucharest }\end{array}$ & -23.5 & 3.5 & 26.6 & 0.2 \\
\hline 16 & MARKETSCOPE, Bucharest & 128.2 & 3.5 & 24.5 & 194.0 \\
\hline 17 & MEDNET, Bucharest & -38.2 & 56.0 & 44.0 & 38.9 \\
\hline 18 & $\begin{array}{l}\text { MEMRB ROMANIA RETAIL TRACKING } \\
\text { SERVICES, Bucharest }\end{array}$ & & & 67.0 & 88.8 \\
\hline 19 & MERCURY RESEARCH, Bucharest & 3.1 & 41.0 & -3.6 & 40.1 \\
\hline 20 & METRO MEDIA TRANSILVANIA, Cluj & 7.1 & -21.1 & 28.2 & 8.2 \\
\hline 21 & $\begin{array}{l}\text { RESEARCH INTERNATIONAL - MARKET } \\
\text { RESEARCH, Bucharest }\end{array}$ & 130.3 & 48.1 & 13.6 & 287.6 \\
\hline 22 & SYNOVATE, Bucharest & m.d. & m.d. & 165.5 & m.d. \\
\hline 23 & $\begin{array}{l}\text { THE GALLUP ORGANIZATION, ROMÂNIA, } \\
\text { Bucharest }\end{array}$ & 36.3 & 51.7 & -20.5 & 64.4 \\
\hline 24 & TNS AGB INTERNATIONAL, Bucharest & 51.3 & 15.5 & 38.6 & 142.2 \\
\hline 25 & VISIONWISE CONSULTING, Bucharest & 2.1 & -3.8 & -98.9 & -98.9 \\
\hline 26 & 360INSIGHTS, București & m.d. & 146.4 & 14.1 & m.d. \\
\hline
\end{tabular}

\section{Marketing research in Romania after 2008}

Starting with 2009 , as result of economic crisis, which significantly affected the marketing budgets of agents acting locally, marketing research market entered a downward trend. In fact, the involution was observed worldwide (and not just locally), the marketing research

\footnotetext{
${ }^{7}$ Real increases and decreases for turnover are shown. CPI was used for this purpose served by the NIS average year (http://www.insse.ro).
} 
market following the trend required by the overall economic development. Basically, the economic crisis effects have been felt in the global marketing research market prior to 2009, research marketing market in Romania knowing the effects with relative delay.

Not having on disposition information with on a higher presence level concerning the income of organizations acting in the domestic market of marketing research, we reproduce below, with purely indicative purpose, the turnover dynamic derived from activities of advertising and market research, data reported by INS up to January 2010. An upward trend of turnover by late 2008 may be observed (just as shown by the indicators presented earlier on turnover of key market operators in marketing research). The year 2009 marks the decline of the market research marketing and advertising; decline that probably will be attenuated simultaneously with the overall economic recovery. (Figure no. 2).

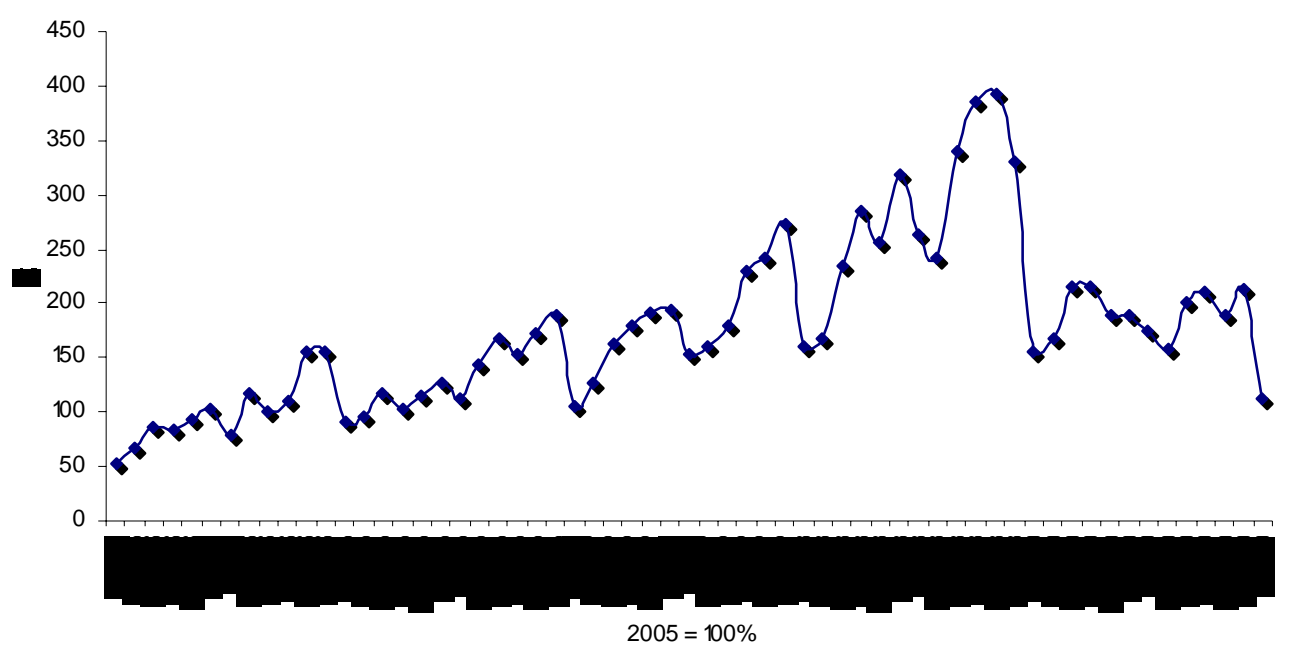

Figure no. 2. Dynamics of monthly turnover of market research and advertising activities (\% vs. 2005) ${ }^{9}$

Source: http://www.insse.ro/ (TEMPO-Online - Time Series)

In conclusion, marketing research market in Romania met until 2008 a sustainable development, being in agreement with overall economic development. With the emergence of economic crisis, profile organizations have registered decreases in revenues, a result of reduced marketing budgets of the organizations - potential customers acting in the national market. Marketing research market in Romania can be broadly described as being dominated by foreign companies that operate globally, a phenomenon manifested by the concentration of market activity at a relatively small number of competitors. In addition to foreign companies, Romanian companies have managed to prevail in this market, one of them Daedalus manages to be at the top five competitors in terms of realized revenue, according to data for 2008 .

\footnotetext{
${ }^{8} \mathrm{http} / /$ www.revista-piata.ro/articole/research/criza-ne-a-invatat-sa-fim-mai-ieftini-oferind-aceeasicalitate.html

9 Indicator communicated by INS: Turnover indices for market services especially made for enterprises. Gross series - base year 2005. Division “Advertising and market research activities”.)
} 


\section{Studies and Scientific Researches - Economic Edition, no. 15, 2010}

\section{Bibliography}

1. Boier, Rodica, Laura C. Țimiraş. (2006), Marketing Research, Performantica Publishing, Iaşi

2. Media \& Advertising Yearbook, 2009, Telegraph

3. Media \& Advertising Yearbook, 2010, Telegraph

4. Wall Strett Journal

5. Market Magazine

6. Economic Tribune Magazine

7. http://www.insse.ro

8. http://www.money.ro

9. http://mcir.doingbusiness.ro/ro/servicii-profesionale-si-de-afaceri

10. http://www.mfinante.ro

11. http://sociologie.dreamstyler.ro/marketing.htm 